\title{
Article \\ Effect of Poly(Titanium Oxide) on the Viscoelastic and Thermophysical Properties of Interpenetrating Polymer Networks
}

\author{
Tamara Tsebriienko ${ }^{1}$ and Anatoli I. Popov ${ }^{2, *}$ \\ 1 Institute of Physics, National Academy of Sciences of Ukraine, 46, pr. Nauky, 03028 Kyiv, Ukraine; \\ mara8@ukr.net \\ 2 Institute of Solid State Physics, University of Latvia, Kengaraga 8, LV-1063 Riga, Latvia \\ * Correspondence: popov@latnet.com
}

Citation: Tsebriienko, T.; Popov, A.I. Effect of Poly(Titanium Oxide) on the Viscoelastic and Thermophysical Properties of Interpenetrating Polymer Networks. Crystals 2021, 11, 794. https://doi.org/10.3390/ cryst11070794

Academic Editors: Kil Sik Min and Ulli Englert

Received: 28 February 2021

Accepted: 4 July 2021

Published: 7 July 2021

Publisher's Note: MDPI stays neutra with regard to jurisdictional claims in published maps and institutional affiliations.

Copyright: (c) 2021 by the authors. Licensee MDPI, Basel, Switzerland. This article is an open access article distributed under the terms and conditions of the Creative Commons Attribution (CC BY) license (https:/ / creativecommons.org/licenses/by/ $4.0 /)$.

\begin{abstract}
The influence of poly(titanium oxide) obtained using the sol-gel method in 2-hydroxyethyl methacrylate medium on the viscoelastic and thermophysical properties of interpenetrating polymer networks (IPNs) based on cross-linked polyurethane (PU) and poly(hydroxyethyl methacrylate) (PHEMA) was studied. It was found that both the initial (IPNs) and organo-inorganic interpenetrating polymer networks (OI IPNs) have a two-phase structure by using methods of dynamic mechanical analysis (DMA) and differential scanning calorimetry (DSC). The differential scanning calorimetry methods and scanning electron microscopy (SEM) showed that the presence of poly(titanium oxide) increases the compatibility of the components of IPNs. It was found that an increase in poly(titanium oxide) content leads to a decrease in the intensity of the relaxation maximum for PHEMA phase and an increase in the effective crosslinking density due to the partial grafting of the inorganic component to acrylate. It was shown that the topology of poly(titanium oxide) structure has a significant effect on the relaxation behavior of OI IPNs samples. According to SEM, a uniform distribution of the inorganic component in the polymer matrix is observed without significant aggregation.
\end{abstract}

Keywords: poly(titanium oxide); sol-gel method; interpenetrating polymer networks; 2-hydroxyethyl methacrylate; polyurethane

\section{Introduction}

In the last decade, due to the high rates of development of various industries, there is a need to obtain materials with the desired set of new operational properties. Therefore, the development of new hybrid organic-inorganic nanocomposites is a topical area of polymer chemistry [1-12]. In this case, the concept of "hybrid" emphasizes the chemical nature of the interaction of system components [13]. Such materials demonstrate not only improved properties of the organic matrix, but also the appearance of new, specific properties that are not inherent to the organic component due to the presence of an inorganic one. Particular attention is drawn to organic-inorganic materials containing titanium, due to their potential application as photocatalyst and membrane, as well as in solar and fuel cells, biomedicine and in other areas, where their unique optical properties can be used [14-30]. In particular, in [25], one of the most extensively studied polymers in biomedical applications, namely, PHEMA incorporated with $\mathrm{TiO}_{2}$ nanoparticles and the appropriate bioactive behavior of such nanocomposite was investigated in detail. It is especially important to mention here that the formation of bone-like apatite, which is a necessary condition for a synthetic material to be considered bioactive [25]. The optically transparent $\mathrm{TiO}_{2}$ particles incorporated in PHEMA thin films were prepared in [26], where their photocatalytic activity was successfully demonstrated. Another important result that needs to be mentioned is the synthesis of PHEMA hydrogels containing low concentration of $\mathrm{TiO}_{2}$ nanoparticles, which show their potential use for cell implantation experiments in vivo [27]. The 
enhanced mechanical and thermal properties of $\mathrm{TiO}_{2}$ nanocomposites reinforced with photo-resin via 3-dimensional printing were recently shown in [28]. Another interesting report [29] is about the excellent UV shielding properties of poly(methylmethacrylate) PMMA/oxide nanocomposites with different types of nanoparticles, which could be used in variety of applications such as sunscreens, aerospace, and several other fields related to UV photodegradation. It is important to note that the thermal and mechanical properties of PMMA-titania nanocomposites and their degradation behavior was discussed in detail in [30]. Note also that nanoporous anatase layers may become interesting for nonlinear optical applications [31].

It is also known from the literature that poly(titanium oxide) gels obtained using the sol-gel method have high photocatalytic activity [32]. They exhibit unique optical properties, i.e., $\mathrm{UV}$-induced transition $\mathrm{Ti}^{4+} \leftrightarrow \mathrm{Ti}^{3+}$. When light is absorbed in a semiconductor, electrons in the conduction band (CB) and positive holes in the valence band (VB) are formed. Light holes can rapidly move to the metal oxide network interface and initiate chemical reactions with environmental molecules. Heavier CB-electrons move on a shorter distance and then are trapped on $\mathrm{Ti}^{4+}$ of the metal oxide network as $\mathrm{Ti}^{3+}$, which can also be situated at the interface. These trapped electrons can be visualized with a strong absorption in the UV-visible-nearIR spectral range with a maximum at $\sim 600_{-100}^{+200} \mathrm{~nm}$, which depends on the sample preparation conditions. The disadvantage of gel materials that limits their use is their mechanical instability, and the advantages for applications in photonics are their transparency and unique photosensitivity, therefore it is actually the choice of the polymer matrix to stabilize the gel while maintaining its structure and, accordingly, the sensitivity. The problem can be solved by creating the hybrid optically transparent organic-inorganic material, which combines valuable properties of organic and inorganic components.

In light of this problem, the synthesis of $\mathrm{TiO}_{2}$-containing organic-inorganic copolymers seems promising. In the previous research, the materials containing the nanostructured poly(titanium oxide) uniformly distributed over the volume of the polymer matrix were synthesized from the titanium alkoxides using the sol-gel method in 2-hydroxyethyl methacrylate (HEMA) medium [33-35]. The materials showed a photochromic transition $\mathrm{Ti}^{4+} \leftrightarrow \mathrm{Ti}^{3+}$ with a quantum yield $>50 \%$. In [36], a new polymeric material was developed, containing nanostructured poly(titanium oxide) in an organic copolymers of hydroxyethyl methacrylate and acrylonitrile and modified by F-content agent, which demonstrate photocatalytic activity in the decomposition reaction of organic pollutants and the self-cleaning effect. Recent studies have also shown the prospect of using such hybrid materials in the field of photonics, especially for 3D laser microstructure and optical information recording [37].

The sol-gel method is commonly used for obtaining the organic-inorganic composites with a uniform distribution of the inorganic nanodispersed phase even at the molecular level [38-48]. The important feature of this process is the ability to regulate the structure of the inorganic component in the organic matrix by controlling the conditions of the hydrolysis-condensation reactions.

It is also of interest to obtain organo-inorganic hybrid materials containing poly(titanium oxide) in which interpenetrating polymer networks (IPNs) act as an organic matrix, especially since research in this direction has not yet been carried out. Among the variety of composite materials, interpenetrating polymer networks attract particular attention due to the possibility of both modifying the properties of cross-linked polymers and obtaining new materials with a wide range of different properties [49,50]. Interpenetrating polymer networks are a combination of two or more polymers in networks where a partial interlacing on the molecular scale is present in the matrix. There is no covalent bonding and therefore the polymers cannot be separated unless the chemical bonds are broken [50]. This morphology of interpenetrating polymer networks can lead to synergistic properties of the initial components. However, for IPNs, as for most organic polymers, such disadvantages as low mechanical properties and thermal stability are inherent. To overcome these defects, 
these materials can be strengthened by the addition of an inorganic component. For these purposes, silica was used successfully [51,52].

When creating the new composite materials, it is important to study the characteristics that determine their phase structure, thermal modes of use, stability and mechanical strength, especially since the structure and properties of organic-inorganic nanocomposites are largely dependent on the content of the nanofiller and its distribution in the organic matrix.

This work aims to study the effect of poly(titanium oxide) obtained using the sol-gel method in HEMA medium by varying the content of inorganic component and a molar ratio of titanium isopropoxide to water on viscoelastic and thermophysical properties of OI IPNs.

\section{Experimental}

The following reagents were used in this study: Titanium (IV) isopropoxide ((Ti(OPri $\left.)_{4}\right)$, 97.0\% purity, Sigma-Aldrich) was used without further purification. 2-Hydroxyethyl methacrylate (HEMA, 99.3\% purity, Merck, Darmstadt, Germany) was used without further purification. Toluylene diisocyanate (TDI, Merck, Darmstadt, Germany), which is a mixture of 2.4- and 2.6-toluylene diisocyanate (ratio 80/20) was distilled before use. Poly(propylene) glycol $\left(\mathrm{M}_{\mathrm{n}}=1000 \mathrm{~g} / \mathrm{mol}\right)$ (PPG, Sigma-Aldrich, St. Louis, MO, USA) was dried under vacuum at $(80 \pm 5){ }^{\circ} \mathrm{C}$ for $4 \mathrm{~h}$ before the use. Trimethylolpropane (TMP, 99\% purity, Merck, Darmstadt, Germany) was dried under vacuum at $40{ }^{\circ} \mathrm{C}$ for $5 \mathrm{~h}$ before the use. 2.2'-Azobis(2-methylbutyronitrile) (AIBN, Sigma-Aldrich, St. Louis, MO, USA) was recrystallized from ethanol before use. The solution of $0.1 \mathrm{~N}$ hydrochloric acid $(\mathrm{HCl})$ was prepared from a standardized solution. The distilled $\mathrm{H}_{2} \mathrm{O}$ was used as the solvent.

Organic-inorganic interpenetrating polymer networks are obtained on the basis of cross-linked polyurethane, poly(hydroxyethyl methacrylate) and poly(titanium oxide). Synthesis of poly(titanium oxide) was carried out by the hydrolytic polycondensation of $\mathrm{Ti}\left(\mathrm{OPr}^{\mathrm{i}}\right)_{4}$ in the presence of hydrochloric acid in the medium of the initial component of IPNs-HEMA. The molar ratio of $\mathrm{Ti}\left(\mathrm{OPr}^{\mathrm{i}}\right)_{4} / \mathrm{HEMA}$ was $1 / 16 ; 1 / 12$ and $1 / 8$, which calculated as $\mathrm{TiO}_{2}$ was 3.8; 5.1 and $7.4 \mathrm{wt} \%$ respectively. The hydrolysis of $\mathrm{Ti}\left(\mathrm{OPr}^{\mathrm{i}}\right)_{4}$ was carried out at the rate of $\mathrm{Ti}\left(\mathrm{OPr}^{\mathrm{i}}\right)_{4} / \mathrm{H}_{2} \mathrm{O}=1 / 1$ and $1 / 2 \mathrm{~mol}$. The reaction mixture was stirred vigorously for $3 \mathrm{~h}$ followed by the formation of poly(titanium oxide) for $48 \mathrm{~h}$. Finally, transparent orange-colored liquid systems were obtained and evacuated at $40{ }^{\circ} \mathrm{C}$ with a residual pressure of 10-20 $\mathrm{mmHg}$ for removing the by-products of hydrolysis-condensation reactions; water and isopropyl alcohol.

The urethane component of OI IPNs was obtained in two stages. At the first stage macrodiisocyanate (MDI) was synthesized by the interaction of TDI and PPG with the ratio $\mathrm{NCO} / \mathrm{OH}=2 / 1$. At the second stage, TMP as the cross-linking agent was added to MDI at the molar ratio $\mathrm{MDI} / \mathrm{TMP}=3 / 2$. The reaction was carried out at $70{ }^{\circ} \mathrm{C}$ and with vigorous stirring for $15 \mathrm{~min}$.

Furthermore, HEMA containing poly(titanium oxide) and AIBN initiator of radical polymerization with a concentration of $0.025 \mathrm{~mol} / \mathrm{L}$ was added to the urethane component to form OI IPNs. The initial IPNs were obtained on the basis of PU and PHEMA without poly(titanium oxide) as described above. The ratio of PU/PHEMA components in the initial and OI IPNs was 30/70 wt $\%$. For obtaining the films of IPNs/OI IPNs, the reaction mixture was poured into sealed forms, followed by polymerization at $60{ }^{\circ} \mathrm{C}(20 \mathrm{~h})$ and $100{ }^{\circ} \mathrm{C}(3 \mathrm{~h})$.

IR spectra of HEMA-containing poly(titanium oxide) were recorded on a Bruker Tensor-37 Fourier spectrometer (Bruker Optics, Ettlingen, Germany) in the frequency range $400-4000 \mathrm{~cm}^{-1}$ with a resolution of $4 \mathrm{~cm}^{-1}$ by applying the test material to KBr plates.

The viscoelastic properties of the initial IPNs and OI IPNs samples were studied by DMA (Dynamic Mechanical Analyzer Q 800, TA Instruments, New Castle, DE, USA). To measure the viscoelastic properties, polymer films with a size of $50 \mathrm{~mm} \times 5 \mathrm{~mm}$ $(0.2-0.5) \mathrm{mm}$ were used. The measurements were performed in the tension mode at a frequency of $10 \mathrm{~Hz}$, and the heating rate was $2.0^{\circ} \mathrm{C} / \mathrm{min}$. 
The values of glass transition temperature $\left(T_{g}\right)$ were determined by the position of the maximum of the tangent of mechanical losses $(\tan \delta)$. The molecular weight of the chain segments between crosslinks $\left(M_{\mathcal{C}}\right)$ was calculated via the equation [53]:

$$
M_{c}=\frac{3 \rho \cdot R \cdot T}{E_{\infty}}
$$

where $\rho$ is the density of the polymer; $R$ is the gas constant; $T$ is the value of absolute temperature; and $E_{\infty}$ is the value of the equilibrium elastic modulus.

Thermophysical properties of the initial IPNs and OI IPNs were studied by DSC method using Differential Scanning Calorimeter Q 2000 (TA Instruments, New Castle, DE, USA) in a nitrogen atmosphere in the temperature range from 273 to $693 \mathrm{~K}$ and heating rate of $2.0^{\circ} \mathrm{C} / \mathrm{min}$.

Samples weighing $0.01-0.015 \mathrm{~g}$ were placed in aluminum capsules which were then sealed. The heating/cooling scan-mode was used. The midpoint of the endothermic transition on the curve of the temperature dependence of heat capacity $\left(C_{p}\right)$ corresponded to $\mathrm{T}_{\mathrm{g}}$ value of the polymer.

The fraction of the interfacial region $(1-F)$ was calculated according to the simplified Fried approximation for partially compatible multicomponent polymer systems [54] based on DSC data:

$$
(1-F)=1-\frac{W_{1} \Delta C_{p 1}+W_{2} \Delta C_{p 2}}{W_{1} \Delta C_{p 1}^{0}+W_{2} \Delta C_{p 2}^{0}}
$$

where: $W_{1}$ and $W_{2}$ are the mass fractions of the components in the mixture; $\Delta C_{p 1}$ and $\Delta C_{p 2}$ are the heat capacity increments of the phases that have released; and $\Delta C_{p 1}^{0}$ and $\Delta C_{p 2}^{0}$ are increments of heat capacity of individual polymers.

To analyze the morphology features of the investigated compositions, the film samples were split using liquefied nitrogen. The surface of the transverse cleavages was examined by scanning electron microscopy (SEM) using a JSM-35-C microscope (JEOL, Tokyo, Japan) at an accelerating voltage of $30 \mathrm{kV}$ and an increase of $\times 2000$. To prevent the accumulation of surface charge and increase the contrast on the fractured surface a plasma deposition of a gold layer $\sim 4 \mathrm{~nm}$ thick was carried out using a Neo Coater installation (JEOL, Tokyo, Japan).

\section{Results and Discussion}

To understand the processes occurring at the stage of the formation of poly(titanium oxide) in HEMA medium with varying the molar ratio $\mathrm{Ti}\left(\mathrm{OPr}^{\mathrm{i}}\right)_{4} / \mathrm{H}_{2} \mathrm{O}$, the IR spectra were studied (Figure 1). The appearance of a low-intensity absorption band at $624 \mathrm{~cm}^{-1}$ for curves 2 and 3 relative to 1 is associated with the vibrations of Ti-O-Ti-groups of poly(titanium oxide) $[55,56]$. An increase in the relative intensity of $\vee \mathrm{C}=\mathrm{O}$ groups at $1720 \mathrm{~cm}^{-1}$ is observed 1.5 times for curve 2 and 1.2 times for curve 3 relative to the spectrum of the initial HEMA (curve 1), and the appearance of a new band at $1522 \mathrm{~cm}^{-1}$ is explained by the formation of complex interactions by the donor-acceptor mechanism (Figure 2) $[57,58]$. The relative intensity of the stretching band at $1170 \mathrm{~cm}^{-1}$ ( $\left.v \mathrm{C}-\mathrm{O}-\right)$ for poly(titanium oxide) in HEMA also increases by 1.5 and 1.2 times obtained at a molar ratio of $\mathrm{Ti}\left(\mathrm{OPr}^{\mathrm{i}}\right)_{4} / \mathrm{H}_{2} \mathrm{O}=1 / 1$ and $\mathrm{Ti}\left(\mathrm{OPr}^{\mathrm{i}}\right)_{4} / \mathrm{H}_{2} \mathrm{O}=1 / 2$, respectively. The increase in the relative intensity of the band at $1170 \mathrm{~cm}^{-1}$ is associated with the partial formation of poly(titanium oxide)-oxoethyl methacrylate (Figure 3) [59]. 

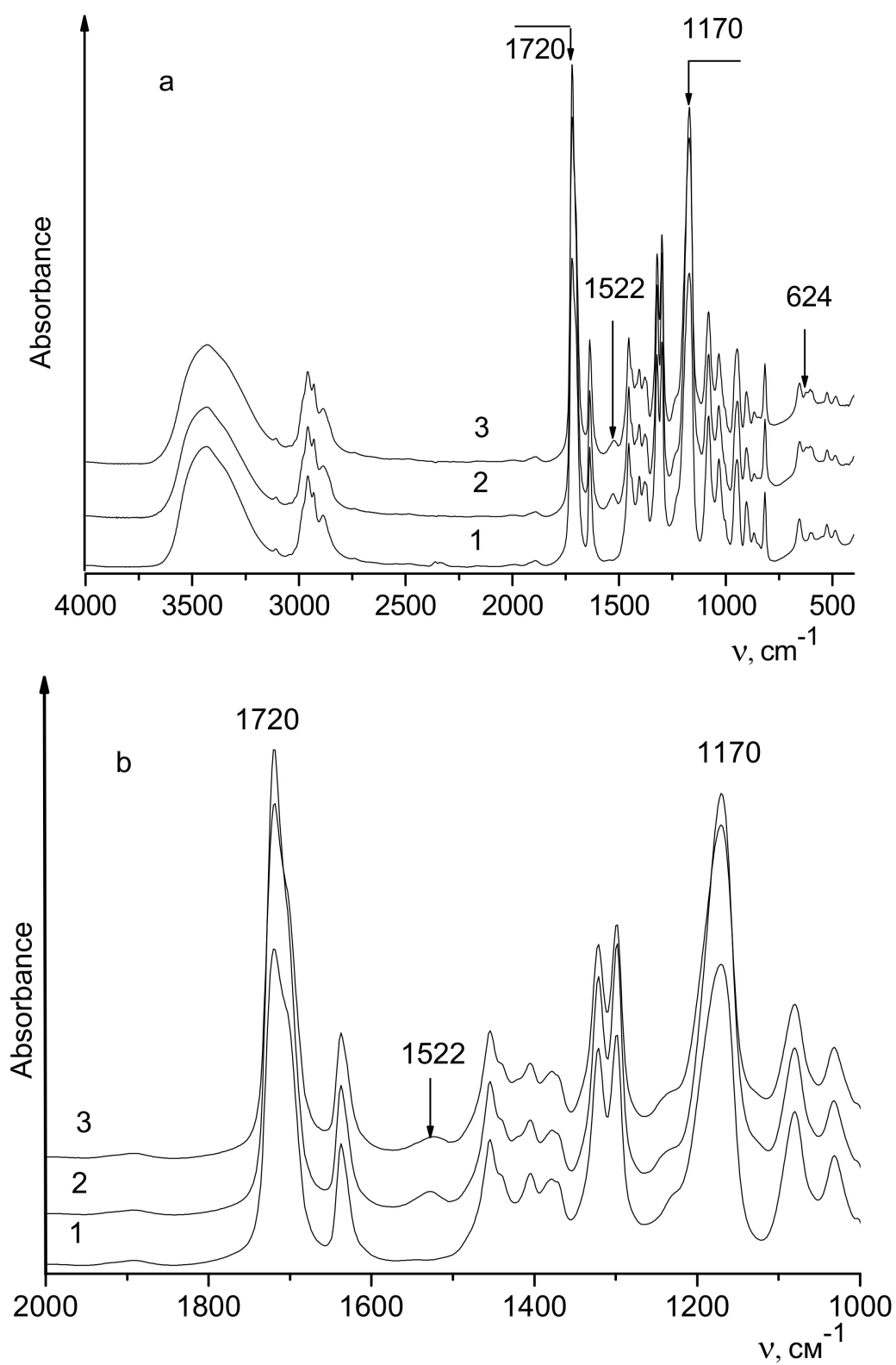

Figure 1. FTIR spectra (a,b) of HEMA (1) and poly(titanium oxide) in HEMA at molar ratio Ti( $\left(\mathrm{OPr}^{\mathrm{i}}\right)_{4}$ to $\mathrm{H}_{2} \mathrm{O}: 1 / 1$ (2) and $1 / 2(3)$.<smiles>C=C(C)C(=O)OCCO</smiles>

Figure 2. The complex interaction, where $\mathrm{OPr}^{\mathrm{i}}$ is the alkoxide group. 
<smiles>C=C(C)C(=O)OCCO[Te](O[In]OC)(O[In]OC)OC(C)C</smiles>

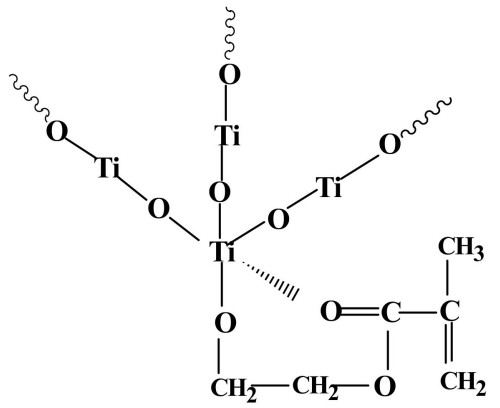

Figure 3. Possible structures of poly(titanium oxide) in HEMA obtained by varying the molar ratio $\mathrm{Ti}\left(\mathrm{OPr}^{\mathrm{i}}\right)_{4} / \mathrm{H}_{2} \mathrm{O}$.

Thus, not only was the formation of poly(titanium oxide) in the HEMA medium during sol-gel synthesis established by using FTIR spectroscopy, but also the appearance of complex interactions by the donor-acceptor mechanism and the nucleophilic substitution reaction with the formation of poly(titanium oxide)-oxoethyl methacrylate. Additionally, it is worth noting that the amount of water that takes part in the hydrolysis of $\operatorname{Ti}\left(\mathrm{OPr}^{\mathrm{i}}\right)_{4}$ directly affects both the presence of unreacted alkoxide groups and the structure of the resulting poly(titanium oxide) as a whole. In the middle of the twentieth century, R. Field and P. Kouv found that linear structure of poly(titanium oxide) is predominantly formed when $\mathrm{Ti}\left(\mathrm{OPr}^{\mathrm{i}}\right)_{4} / \mathrm{H}_{2} \mathrm{O} \geq 1$ ratio and branched one with a molar ratio of $\mathrm{Ti}\left(\mathrm{OPr}^{\mathrm{i}}\right)_{4} / \mathrm{H}_{2} \mathrm{O}<1$ (Figure 3) [60].

Dynamic mechanical analysis is one of the most widespread methods of studying the relaxation properties of polymer composites which allows the number of values (dynamic modulus, the tangent of mechanical losses, glass transition temperature, etc.) which have both fundamental and practical significance to be determined [53]. Therefore in this study, it was advisable to consider the influence of poly(titanium oxide) as well as its topology on the viscoelastic properties of OI IPNs. The temperature dependences of $\tan \delta$ for IPNs and OI IPNs with the varying of the content of poly(titanium oxide) and the molar ratio of $\mathrm{Ti}\left(\mathrm{OPr}^{\mathrm{i}}\right)_{4} / \mathrm{H}_{2} \mathrm{O}$ are shown in Figure 4 . The parameters of the relaxation transitions, the values of $E_{\infty}$ and $M_{c}$ for the studied systems, are presented in Table 1.

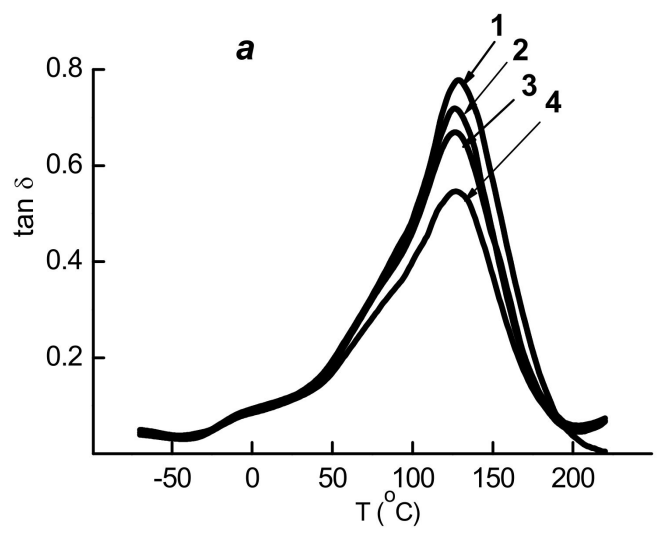

(a)

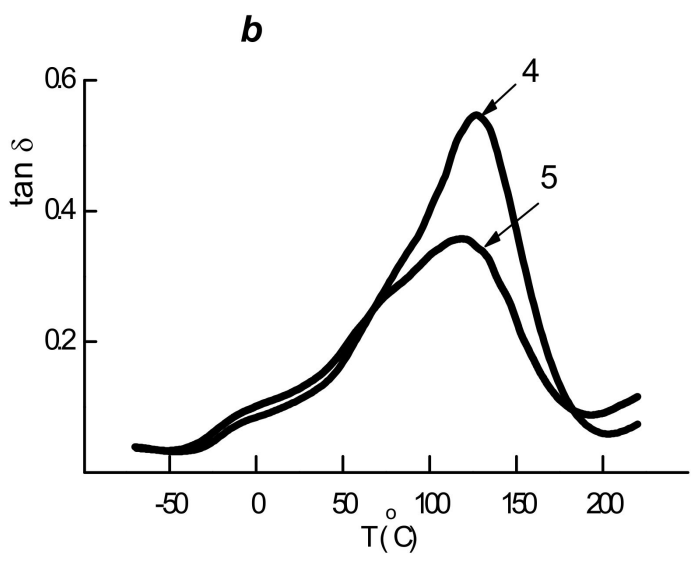

(b)

Figure 4. Temperature dependencies of $\tan \delta(\mathbf{a}, \mathbf{b})$ for the samples of the IPNs (1), OI IPNs-1 (2), OI IPNs-2 (3), OI IPNs-3 (4), OI IPNs-4 (5). The composition of the samples is given in Table 1. 
Table 1. Viscoelastic properties of IPNs and OI IPNs.

\begin{tabular}{|c|c|c|c|c|c|c|}
\hline \multirow{2}{*}{ Samples } & \multirow{2}{*}{$\begin{array}{c}\text { PU/PHEMA/TiO }{ }_{2} * \\
\text { wt } \%\end{array}$} & \multirow{2}{*}{$\mathrm{Ti}\left(\mathrm{OPr}^{\mathrm{i}}\right)_{4 /} \mathrm{H}_{2} \mathrm{O}, \mathrm{mol}$} & \multicolumn{2}{|c|}{ PHEMA Phase } & \multirow{2}{*}{$E_{\infty} \mathbf{M P a}$} & \multirow{2}{*}{$M_{c}$} \\
\hline & & & $T_{g 2,}{ }^{\circ} \mathrm{C}$ & $\tan \delta_{\max 2}$ & & \\
\hline IPNs & $30.0 / 70.0 / 0$ & - & 128 & 0.78 & 3.7 & 3760 \\
\hline OI IPNs-1 & $29.30 / 68.26 / 2.44$ & $1 / 2$ & 126 & 0.72 & 5.4 & 2600 \\
\hline OI IPNs-2 & $29.05 / 67.73 / 3.22$ & $1 / 2$ & 126 & 0.67 & 6.6 & 2130 \\
\hline OI IPNs-3 & $28.60 / 66.75 / 4.65$ & $1 / 2$ & 126 & 0.54 & 13.2 & 1070 \\
\hline OI IPNs-4 & $28.60 / 66.75 / 4.65$ & $1 / 1$ & 118 & 0.36 & 25.6 & 550 \\
\hline
\end{tabular}

* the content of poly(titanium oxide) in terms of $\mathrm{TiO}_{2} ; E_{\infty}$, the value of the equilibrium elastic modulus; $M_{c}$, the molecular weight of the chain segments between crosslinks.

The $\mathrm{T}_{\mathrm{g}}$ at $128{ }^{\circ} \mathrm{C}$ corresponds to PHEMA [33] and the $\mathrm{Tg}$ at $-5^{\circ} \mathrm{C}$ corresponds to the PU polymer Figure 4a. Such temperature dependence $\tan \delta$ indicates that IPNs is a two-phase system. Similar dependences of $\tan \delta(\mathrm{T})$ are also observed for all samples (curves 2-5), which confirms their two-phase structure.

The study of the viscoelastic characteristics of OI IPNs showed that with an increase in poly(titanium oxide) content, there is a significant decrease in the relaxation transition height for the PHEMA phase (Figure 4a, curves 1-4, Table 1). The reduction in the intensity of the relaxation maximum with the increasing content of the inorganic component is often observed for the nanostructured hybrid systems. It is usually connected with the formation of the dense inorganic network that prevents the segmental mobility of the polymer chains $[57,61]$. In our case, the decrease in $\tan \delta_{\max 2}$ is a result of blocking of the mobility of the significant fraction of the polymer segments (relaxators) involved in the relaxation transition for PHEMA phase. It may occur due to the partial formation of poly(titanium oxide)-oxoethyl methacrylate as a result of exchange reactions between non-hydrolyzed groups of poly(titanium oxide) and HEMA hydroxyl groups and also due to the formation of the complex interaction between $\mathrm{Ti}$ atoms and $\mathrm{C}=\mathrm{O}$-group of HEMA. The presence of such interactions is also supported by the fact that even a slight increase in poly(titanium oxide) content leads to a significant decrease in the $M_{c}$ (the molecular weight of the chain segments between crosslinks) value in OI IPNs (Table 1). This indicates a significant increase in the number of cross-links and/or topological entanglements in the organic-inorganic hybrid polymer system.

It is an interesting fact that the presence of the inorganic component practically does not change the value of $\mathrm{T}_{\mathrm{g} 2}$ (Table 1). Although in the classical sense, the increase in the cross-linking density is usually accompanied by the increase in the glass transition temperature and a corresponding decrease in the $M_{c}$ value. It can be assumed that poly(titanium oxide) in some way acts as a compatibilizer due to both the grafting of the inorganic component to the PHEMA macrochains, but also accidentally interacting with the urethane component due to highly active non-hydrolyzed alkoxide groups. According to the authors, this effect leads to the absence of an increase in the temperature of the acrylate component.

The comparison of the dependencies of $\tan \delta(\mathrm{T})$ for OI IPNs-3 and OI IPNs-4 samples (Figure $4 \mathrm{~b}$ ) with the same content of poly(titanium oxide), but obtained at different molar ratios of $\mathrm{Ti}(\mathrm{OPr} \mathrm{i})_{4} / \mathrm{H}_{2} \mathrm{O}$ showed that the topology of inorganic component influences the phase structure of OI IPNs. This is evidenced by a change in the parameters of the relaxation transition for PHEMA phase, as well as a 2-fold decrease in the $\mathrm{M}_{\mathrm{c}}$ value for OI IPNs-4 compared to OI IPNs-3 sample (Table 1). Perhaps, the linear structure of poly(titanium oxide) which was formed at the molar ratio of $\mathrm{Ti}\left(\mathrm{OPr}^{\mathrm{i}}\right)_{4} / \mathrm{H}_{2} \mathrm{O}=1 / 1$, promotes an increase in the number of the grafting and donor-acceptor interactions. It increases the number of polymer segments with locked mobility and reduces the height of $\tan \delta$ of PHEMA phase (Figure $4 \mathrm{~b}$ ). However, at the branched structure of poly(titanium oxide) which was obtained at the molar ratio $\mathrm{Ti}\left(\mathrm{OPr}^{\mathrm{i}}\right)_{4} / \mathrm{H}_{2} \mathrm{O}=1 / 2$, the number of such interactions may be limited due to the occurrence of steric hindrances and the deficiency of alkoxide groups. The comparison of the $\mathrm{M}_{\mathrm{c}}$ values for OI IPNs-3 and OI IPNs-4 samples (Table 1) shows that 
the only change in the topology of poly(titanium oxide) structure from the branched to the linear leads to the significant increase in the cross-linking density in OI IPNs.

The results obtained by DSC method also confirm that both the initial IPNs and OI IPNs have a two-phase structure as evidenced by the presence of two heat capacity jumps $\left(\Delta C_{p}\right)$ on the temperature dependence of $C_{p}=f(T)$. The glass transition temperature of PU $\left(T_{g 1}\right)$ and PHEMA $\left(T_{g 2}\right)$ were determined from $C_{p}=f(T)$ dependence (Table 2, Figure 5).

Table 2. Thermophysical parameters of relaxation transitions of IPNs and OI IPNs.

\begin{tabular}{|c|c|c|c|c|c|c|c|}
\hline Samples & $\begin{array}{c}\text { PU/PHEMA/ } \\
\mathrm{TiO}_{2}^{*}, \\
w^{*} \%\end{array}$ & $\begin{array}{l}\mathrm{Ti}\left(\mathrm{OPr}^{\mathrm{i}}\right)_{4} / \mathrm{H}_{2} \mathrm{O} \\
\mathrm{mol}\end{array}$ & $\begin{array}{c}\mathrm{T}_{\mathrm{g1}} \mathrm{PU}- \\
\text { Enriched } \\
\text { Phase, }{ }^{\circ} \mathrm{C}\end{array}$ & $\begin{array}{c}\mathrm{T}_{\mathrm{g} 2} \text { PHEMA- } \\
\text { Enriched } \\
\text { Phase, }{ }^{\circ} \mathrm{C}\end{array}$ & $\begin{array}{c}\Delta \mathrm{C}_{\mathrm{pPU}} \\
\mathrm{kJ} /(\mathrm{kg} \mathrm{K})\end{array}$ & $\begin{array}{c}\Delta \mathrm{C}_{\text {pPHEMA }} \\
\mathrm{kJ} /(\mathrm{kg} \mathrm{K})\end{array}$ & $1-F$ \\
\hline PU & $100.0 / 0 / 0$ & - & -18.86 & - & 0.4936 & - & - \\
\hline PHEMA & $0 / 100.0 / 0$ & - & - & 64.51 & - & 0.21 & - \\
\hline IPNs & $30.0 / 70.0 / 0$ & - & -18.44 & 53.32 & 0.1833 & 0.2802 & 0.24 \\
\hline OI IPNs-1 & $29.30 / 68.26 / 2.44$ & $1 / 2$ & -13.78 & 53.19 & 0.2139 & 0.1886 & 0.41 \\
\hline OI IPNs-2 & $29.05 / 67.73 / 3.22$ & $1 / 2$ & -14.33 & 53.53 & 0.1966 & 0.2248 & 0.34 \\
\hline OI IPNs-3 & $28.60 / 66.75 / 4.65$ & $1 / 2$ & -14.65 & 53.08 & 0.231 & 0.1925 & 0.38 \\
\hline
\end{tabular}

*the content of poly(titanium oxide) in terms of $\mathrm{TiO}_{2} ; \Delta \mathrm{C}_{\mathrm{pPU}}$, change in the values of the heat capacity jump of the PU phase; $\Delta \mathrm{C}_{\mathrm{pPHEMA}}$, change in the values of the heat capacity jump of the PHEMA phase.

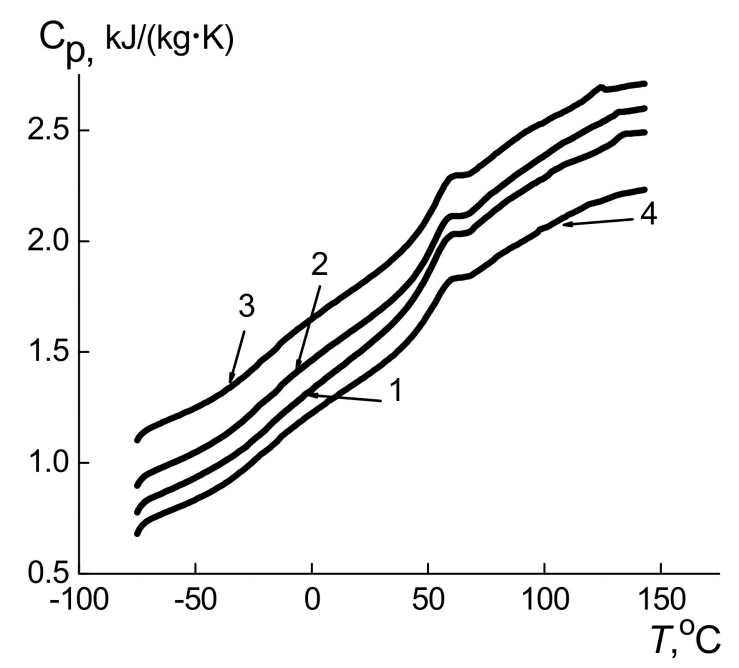

Figure 5. Temperature dependences of heat capacity for IPNs (1); OI IPNs-1 (2), OI IPNs-2 (3), OI IPNs-3 (4). The composition of the samples is given in Table 2.

The results presented in Table 2 show that the introduction of poly(titanium oxide) in IPNs slightly increases the glass transition temperature of the PU phase, but the glass transition temperature of the PEMA phase is practically unchanged. The value of the heat capacity increment for the PU phase slightly increases relative to the initial IPNs with the increase in poly(titanium oxide) content, and it decreases for the PHEMA phase. It should be noted that the nonlinear nature of the change in the values of the heat capacity jump in the PU and PHEMA phases in OI IPNs samples with increasing Ti component. It can be assumed that poly(titanium oxide) not only increases the rigidity of the PHEMA phase due to the partial formation of poly(titanium oxide)-oxoethyl methacrylate, but also possibly acts as a compatibilizer which leads to the absence of increasing $\mathrm{T}_{\mathrm{g} 2}$ value of PHEMA component and a slight increase this parameter for PU component. The results obtained by DSC method confirm the data obtained by DMA method.

Micro-phase separation processes also occur with the formation of the interfacial region (IFR) between the components of IPNs. Each phase can be considered quasiequilibrium with the molecular level of mixing, but in general, these are systems where there is no deep penetration at the molecular level throughout the volume of the system. 
The peculiarity of such systems is that for both IPNs and semi-interpenetrating polymer networks (semi-IPNs) IFR can be considered as a quasi-equal third phase. Its appearance is the result of a spinodal separation mechanism. Phase separation by the spinodal mechanism begins with the formation of a continuously interconnected periodic structure, which gradually shifts to droplet as a result of the decomposition of spinodal structures at the last stages of phase separation due to an increase in the interfacial tension $[62,63]$.

The number of equations was proposed by various authors to evaluate IFR $[53,64]$. They were deduced on the assumption of additivity of heat capacity jumps in partially compatible systems. We used the simplified Fried approximation to calculate the share of $\operatorname{IFR}((1-F))(2)$.

Thus, IFR is absent if $(1-F)=0$; all polymers are in IFR if $(1-F)=1$. The value of the share of the interfacial region calculated in such way is relative.

As is shown in Table 2, the proportion of the interfacial region increases in OI IPNs compared to initial IPNs with increasing of poly(titanium oxide) obtained at a molar ratio of $\mathrm{Ti}\left(\mathrm{OPr}^{\mathrm{i}}\right)_{4} / \mathrm{H}_{2} \mathrm{O}=1 / 2$, which is probably related to the growth of compatibility of IPNs components. This effect is probably due to the partial grafting of poly(titanium oxide) to both PHEMA and PU macrochains during their formation, and/or with a decrease in the phase separation rate at the initial stages of composite formation due to the catalytic effect of the titanium component on the urethane formation reaction and increasing the viscosity of the reaction medium as a whole.

The scanning electron microscopy was used for a more complete understanding of the structure and morphology of the obtained IPNs and OI IPNs containing poly(titanium oxide) synthesized in a HEMA medium.

SEM studies have shown sufficient differences in the morphology of initial IPNs and OI IPNs. The presence of characteristic morphology of the fractured piece of IPNs film, as well as the distribution of color shades in the obtained images (Figure 6a) may indicate phase separation of the components (PU and PHEMA) in the composite.

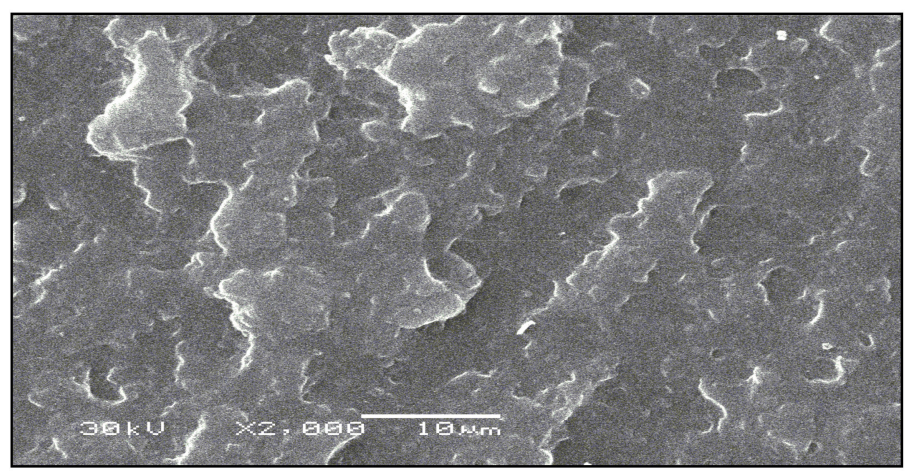

(a) PU/PHEMA 30.0/70.0, wt $\%$

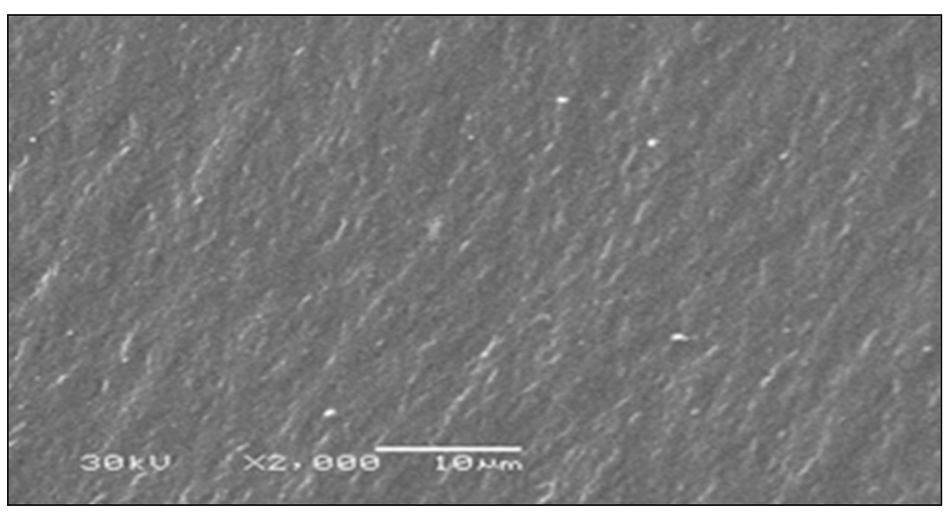

(b) PU/PHEMA/TiO 2 28.60/66.75/4.65, wt\%

Figure 6. SEM images of transverse cleavages of IPNs (a) and OI IPNs (b) samples. 
However, the significant smoothing of the relief of the transverse cleavage surface of OI IPNs sample and the decrease in the color contrast level (Figure 6b) confirm that the introduction of poly(titanium oxide) into the polymer matrix significantly reduces the phase separation level of the hybrid composition.

The obtained results indirectly confirm the presence of the compatibilizing effect of poly(titanium oxide), as well as its influence on the relaxation and thermophysical behavior of the studied samples. Additionally, it is worth noting that the distribution of the inorganic component in the polymer matrix is quite uniform without significant aggregation, which may indicate the presence of the appropriate physicochemical interaction between them. This is especially important for the manufacture of appropriate fluorescent matrices based on $\mathrm{TiO}_{2}$, when the latter is doped with a luminescent impurity [65-67].

\section{Conclusions}

It was established by using DMA and DSC methods that the OI IPNs system is two-phase; however, the increase in the interfacial region share with the increase in poly(titanium oxide) content as well as their morphology according to SEM indicates that the inorganic component acts as a compatibilizer. It was shown by using the DMA method that the increase in poly(titanium oxide) content in OI IPNs leads to a decrease in the relaxation maximum intensity of PHEMA component and the reduction in the molecular weight of the chain segments between the cross-links. Such changes indicate an increase in the effective cross-linking density of OI IPNs due to the partial grafting of poly(titanium oxide) to PEMA. The decrease in the segmental mobility of the polymer chains due to the formation of poly(titanium oxide)-oxoethyl methacrylate is indicated by a decrease in the heat capacity increment of PHEMA component of OI IPNs relative to initial IPNs. It has been shown that the topology of poly(titanium oxide) structure significantly influences the relaxation behavior of the samples.

Author Contributions: Conceptualization, T.T. and A.I.P.; methodology, T.T.; software, T.T.; formal analysis, T.T. and A.I.P.; investigation, T.T.; resources, A.I.P.; data curation, A.I.P.; writing-original draft preparation, T.T. and A.I.P.; writing-review and editing, T.T. and A.I.P.; visualization, T.T.; supervision, A.I.P.; project administration, A.I.P.; funding acquisition, A.I.P. All authors have read and agreed to the published version of the manuscript.

Funding: This study was partly supported by the M-ERA.NET project SunToChem.

Institutional Review Board Statement: Not applicable.

Informed Consent Statement: Not applicable.

Data Availability Statement: Not applicable.

Acknowledgments: The authors thank V. Serga for many useful discussions. The research was (partly) performed in the Institute of Solid State Physics, University of Latvia ISSP UL. ISSP UL as the Center of Excellence is supported through the Framework Program for European universities Union Horizon 2020, H2020-WIDESPREAD-01-2016-2017-Teaming Phase 2 under Grant Agreement No. 739508, CAMART2 project.

Conflicts of Interest: The authors declare no conflict of interest.

\section{References}

1. Pandey, S.; Mishra, S.B. Sol-gel derived organic-inorganic hybrid materials: Synthesis, characterizations and applications. J. Sol Gel Sci. Technol. 2011, 59, 73-94. [CrossRef]

2. Canto, C.F.; Prado, L.D.A.; Radovanovic, E.; Yoshida, I.V.P. Organic-inorganic hybrid materials derived from epoxy resin and polysiloxanes: Synthesis and characterization. Polym. Eng. Sci. 2008, 48, 141-148. [CrossRef]

3. Wang, S.; Kang, Y.; Wang, L.; Zhang, H.; Wang, Y.; Wang, Y. Organic/inorganic hybrid sensors: A review. Sens. Actuators Chem. B 2013, 182, 467-481. [CrossRef]

4. Karbovnyk, I.; Klym, H.; Piskunov, S.; Popov, A.A.; Chalyy, D.; Zhydenko, I.; Lukashevych, D. The impact of temperature on electrical properties of polymer-based nanocomposites. Low Temp. Phys. 2020, 46, 1231-1234. [CrossRef] 
5. Aksimentyeva, O.I.; Savchyn, V.P.; Dyakonov, V.P.; Piechota, S.; Horbenko, Y.Y.; Opainych, I.Y.; Demchenko, P.Y.; Popov, A.; Szymczak, H. Modification of polymer-magnetic nanoparticles by luminescent and conducting substances. Mol. Cryst. Liq. Cryst. 2014, 590, 35-42. [CrossRef]

6. Savchyn, V.P.; Popov, A.I.; Aksimentyeva, O.I.; Klym, H.; Horbenko, Y.Y.; Serga, V.; Moskina, A.; Karbovnyk, I. Cathodoluminescence characterization of polystyrene-BaZrO 3 hybrid composites. Low Temp. Phys. 2016, 42, 597-600. [CrossRef]

7. Karbovnyk, I.; Olenych, I.; Kukhta, A.; Lugovskii, A.; Sasnouski, G.; Olenych, Y.; Luchechko, A.; Popov, A.I.; Yarytska, L. Multicolor photon emission from organic thin films on different substrates. Radiat. Meas. 2016, 90, 38-42. [CrossRef]

8. Zhyhailo, M.; Yevchuk, I.; Yatsyshyn, M.; Korniy, S.; Demchyna, O.; Musiy, R.; Raudonis, R.; Zarkov, A.; Kareiva, A. Preparation of polyacrylate/silica membranes for fuel cell application by in situ UV polymerization. Chemija 2020, 31, 247-254. [CrossRef]

9. Laurikènas, A.; Mažeika, K.; Baltrūnas, D.; Skaudžius, R.; Beganskienè, A.; Kareiva, A. Hybrid organic-inorganic Fe 3 O $(\mathrm{TFBDC})_{3}\left(\mathrm{H}_{2} \mathrm{O}\right)_{3} \cdot(\mathrm{DMF})_{3}$ compound synthesized by slow evaporation method: Characterization and comparison of magnetic properties. Lith. J. Phys. 2020, 60, 78. [CrossRef]

10. Kiele, E.; Lukseniene, J.; Griguceviciene, A.; Selskis, A.; Senvaitiene, J.; Ramanauskas, R.; Raudonis, R.; Kareiva, A. Methylmodified hybrid organic-inorganic coatings for the conservation of copper. J. Cult. Herit. 2014, 15, 242-249. [CrossRef]

11. Aksimentyeva, O.; Konopelnyk, O.; Bolesta, I.; Karbovnyk, I.; Poliovyi, D.; Popov, A.I. Charge transport in electrically responsive polymer layers. J. Phys. Conf. Ser. 2007, 93, 012042. [CrossRef]

12. Aksimentyeva O, I.; Chepikov, I.B.; Filipsonov, R.V.; Malynych, S.Z.; Gamernyk, R.V.; Martyniuk, G.V.; Horbenko, Y.Y. Hybrid composites with low reflection of IR radiation. Phys. Chem. Solid State 2020, 21, 764-770. [CrossRef]

13. Kickelbick, G. Introduction to hybrid materials. In Hybrid Materials: Synthesis, Characterization, and Applications; Wiley-VCH Verlag GmbH \& Co.: Weinheim, Germany, 2007; pp. 1-48.

14. Sabah, F.A.; Razak, I.A.; Kabaa, E.A.; Zaini, M.F.; Omar, A.F. Characterization of hybrid organic/inorganic semiconductor materials for potential light emitting applications. Opt. Mater. 2020, 107, 110117. [CrossRef]

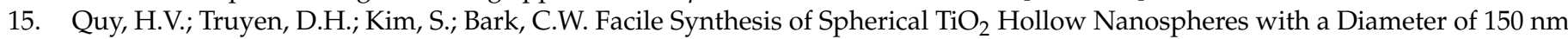
for High-Performance Mesoporous Perovskite Solar Cells. Materials 2021, 14, 629. [CrossRef]

16. Li, Y.; Wang, W.; Wang, F.; Di, L.; Yang, S.; Zhu, S.; Yao, Y.; Ma, C.; Dai, B.; Yu, F. Enhanced Photocatalytic Degradation of Organic Dyes via Defect-Rich $\mathrm{TiO}_{2}$ Prepared by Dielectric Barrier Discharge Plasma. Nanomaterials 2019, 9, 720. [CrossRef]

17. Pant, B.; Park, M.; Park, S.-J. Recent Advances in $\mathrm{TiO}_{2}$ Films Prepared by Sol-Gel Methods for Photocatalytic Degradation of Organic Pollutants and Antibacterial Activities. Coatings 2019, 9, 613. [CrossRef]

18. Ramirez, L.; Ramseier Gentile, S.; Zimmermann, S.; Stoll, S. Behavior of $\mathrm{TiO}_{2}$ and $\mathrm{CeO}_{2}$ Nanoparticles and Polystyrene Nanoplastics in Bottled Mineral, Drinking and Lake Geneva Waters. Impact of Water Hardness and Natural Organic Matter on Nanoparticle Surface Properties and Aggregation. Water 2019, 11, 721. [CrossRef]

19. Zhao, W.; Yang, X.; Liu, C.; Qian, X.; Wen, Y.; Yang, Q.; Sun, T.; Chang, W.; Liu, X.; Chen, Z. Facile Construction of All-Solid-State Z-Scheme $\mathrm{g}-\mathrm{C}_{3} \mathrm{~N}_{4} / \mathrm{TiO}_{2}$ Thin Film for the Efficient Visible-Light Degradation of Organic Pollutant. Nanomaterials 2020, 10, 600. [CrossRef] [PubMed]

20. Regmi, C.; Lotfi, S.; Espíndola, J.C.; Fischer, K.; Schulze, A.; Schäfer, A.I. Comparison of Photocatalytic Membrane Reactor Types for the Degradation of an Organic Molecule by $\mathrm{TiO}_{2}$-Coated PES Membrane. Catalysts 2020, 10, 725. [CrossRef]

21. Dukenbayev, K.; Kozlovskiy, A.; Kenzhina, I.; Berguzinov, A.; Zdorovets, M. Study of the effect of irradiation with Fe ${ }^{7+}$ ions on the structural properties of thin $\mathrm{TiO}_{2}$ foils. Mater. Res. Express 2019, 6, 046309. [CrossRef]

22. Knoks, A.; Kleperis, J.; Grinberga, L. Raman spectral identification of phase distribution in anodic titanium dioxide coating. Proc. Estonian Acad. Sci. 2017, 66, 422-429. [CrossRef]

23. Kozlovskiy, A.; Shlimas, D.; Kenzhina, I.; Boretskiy, O.; Zdorovets, M. Study of the Effect of Low-Energy Irradiation with O ${ }^{2+}$ Ions on Radiation Hardening and Modification of the Properties of Thin $\mathrm{TiO}_{2}$ Films. J. Inorg. Organomet. Polym. Mater. 2021, 31, 790-801. [CrossRef]

24. Mattsson, M.S.M.; Azens, A.; Niklasson, G.A.; Granqvist, C.G.; Purans, J. Li intercalation in transparent Ti-Ce oxide films: Energetics and ion dynamics. J. Appl. Phys. 1997, 81, 6432-6437. [CrossRef]

25. Prashantha, K.; Rashmi, B.J.; Venkatesha, T.V.; Lee, J.-H. Spectral characterization of apatite formation on poly(2hydroxyethylmethacrylate)- $\mathrm{TiO}_{2}$ nanocomposite film prepared by sol-gel process. Spectrochim. Acta Part A Mol. Biomol. Spectrosc. 2006, 65, 340-344. [CrossRef] [PubMed]

26. Štengl, V.; Houšková, V.; Bakardjieva, S.; Murafa, N.; Havlín, V. Optically Transparent Titanium Dioxide Particles Incorporated in Poly(hydroxyethyl methacrylate) Thin Layers. J. Phys. Chem. C. 2008, 112, 19979-19985. [CrossRef]

27. Toledo, L.; Racine, L.; Pérez, V.; Henríquez, J.P.; Auzely-Velty, R.; Urbano, B.F. Physical nanocomposite hydrogels filled with low concentrations of $\mathrm{TiO}_{2}$ nanoparticles: Swelling, networks parameters and cell retention studies. Mater. Sci. Eng. C 2018, 92, 769-778. [CrossRef]

28. Mubarak, S.; Dhamodharan, D.; Divakaran, N.; Kale, M.B.; Senthil, T.; Wu, L.; Wang, J. Enhanced Mechanical and Thermal Properties of Stereolithography 3D Printed Structures by the Effects of Incorporated Controllably Annealed Anatase $\mathrm{TiO}_{2}$ Nanoparticles. Nanomaterials 2020, 10, 79. [CrossRef]

29. Moustafa, H.; Darwish, D.; Youssef, A.S.; El-Wakil, R.A. High-Performance of Nanoparticles and Their Effects on the Mechanical, Thermal Stability and UV-Shielding Properties of PMMA Nanocomposites. Egypt. J. Chem. 2018, 61, 23-32. [CrossRef] 
30. Motaung, T.E.L.; Luyt, A.S.; Bondioli, F.; Messori, M.; Saladino, M.L.; Spinella Al Nasillo, G.; Caponetti, E. PMMA-titania nanocomposites: Properties and thermal degradation behavior. Polym. Degrad. Stab. 2012, 97, 1325-1333. [CrossRef]

31. Gayvoronsky, V.; Galas, A.; Shepelyavyy, E.; Dittrich, T.; Timoshenko, V.; Nepijko, S.; Brodyn, M.; Koch, F. Giant nonlinear optical response of nanoporous anatase layers. Appl. Phys. B 2005, 80, 97-100. [CrossRef]

32. Kuznetsov, A.I.; Kameneva, O.; Alexandrov, A.; Bityurin, N.; Marteau, P.; Chhor, K.; Sanchez, C.; Kanaev, A. Light-induced charge separation and storage in titanium oxide gels. Phys. Rev. E 2005, 71, 021403. [CrossRef]

33. Salomatina, E.V.; Bityurin, N.M.; Gulenova, M.V.; Gracheva, T.A.; Drozdov, M.N.; Knyazev, A.V.; Kir'yanov, K.V.; Markin, A.V.; Smirnova, L.A. Synthesis, structure, and properties of organic-inorganic nanocomposites containing poly(titanium oxide). J. Mater. Chem. C 2013, 1, 6375-6385. [CrossRef]

34. Salomatina, E.V.; Moskvichev, A.N.; Knyazev, A.V.; Smirnova, L.A. Effect of kinetic features in synthesis of hybrid copolymers based on $\mathrm{Ti}\left(\mathrm{O}^{\mathrm{i}} \mathrm{Pr}\right)_{4}$ and hydroxyethyl methacrylate on their structure and properties. Russian J. Appl. Chem. 2015, 88, 197-207. [CrossRef]

35. Kameneva, O.; Kuznestov, A.I.; Smirnova, L.A.; Rozes, L.; Sanchez, C.; Alexandrov, A.; Bityurin, N.; Chhor, K.; Kanaev, A. New photoactive hybrid organic-inorganic materials based on titanium-oxo-PHEMA nanocomposites exhibiting mixed valence properties. J. Mater. Chem. 2005, 15, 3380-3383. [CrossRef]

36. Ryabkova, O.; Redina, L.; Salomatina, E.; Smirnova, L. Hydrophobizated poly(titanium oxide) containing polymeric surfaces with UV-induced reversible wettability and self-cleaning properties. Surf. Interfaces 2020, 18, 100452. [CrossRef]

37. Fadeeva, E.; Koch, J.; Chichkov, B.; Kuznetsov, A.; Kameneva, O.; Bityurin, N.; Sanchez, C.; Kanaev, A. Laser imprinting of 3D structures in gel-based titanium oxide organic-inorganic hybrids. Appl. Phys. A 2006, 84, 27-30. [CrossRef]

38. Brinker, C.J.; Scherer, G.W. Sol-Gel Science; Academic Press: New York, NY, USA, 1990; 881p.

39. Jonauske, V.; Stanionyte, S.; Chen, S.-W.; Zarkov, A.; Juskenas, R.; Selskis, A.; Matijosius, T.; Yang, T.C.K.; Ishikawa, K.; Ramanauskas, R.; et al. Characterization of Sol-Gel Derived Calcium Hydroxyapatite Coatings Fabricated on Patterned Rough Stainless Steel Surface. Coatings 2019, 9, 334. [CrossRef]

40. Mura, S.; Ludmerczki, R.; Stagi, L.; Garroni, S.; Carbonaro, C.M.; Ricci, P.C.; Casula, M.F.; Malfatti, L.; Innocenzi, P. Integrating sol-gel and carbon dots chemistry for the fabrication of fluorescent hybrid organic-inorganic films. Sci. Rep. 2020, 10, 4770. [CrossRef] [PubMed]

41. Valeikiene, L.; Roshchina, M.; Grigoraviciute-Puroniene, I.; Prozorovich, V.; Zarkov, A.; Ivanets, A.; Kareiva, A. On the Reconstruction Peculiarities of Sol-Gel Derived $\mathrm{Mg}_{2-\mathrm{x}} \mathrm{M}_{\mathrm{x}} / \mathrm{Al}_{1}(\mathrm{M}=\mathrm{Ca}, \mathrm{Sr}, \mathrm{Ba})$ Layered Double Hydroxides. Crystals 2020, 10, 470. [CrossRef]

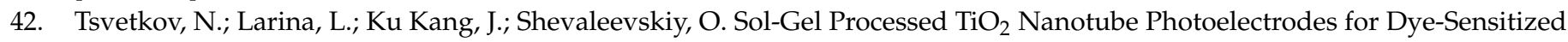
Solar Cells with Enhanced Photovoltaic Performance. Nanomaterials 2020, 10, 296. [CrossRef]

43. Veselov, G.B.; Karnaukhov, T.M.; Bauman, Y.I.; Mishakov, I.V.; Vedyagin, A.A. Sol-Gel-Prepared Ni-Mo-Mg-O System for Catalytic Transformation of Chlorinated Organic Wastes into Nanostructured Carbon. Materials 2020, 13, 4404. [CrossRef] [PubMed]

44. Korolkov, I.V.; Kuandykova, A.; Yeszhanov, A.B.; Güven, O.; Gorin, Y.G.; Zdorovets, M.V. Modification of PET Ion-Track Membranes by Silica Nanoparticles for Direct Contact Membrane Distillation of Salt Solutions. Membranes 2020, $10,322$. [CrossRef]

45. Smalenskaite, A.; Pavasaryte, L.; Yang, T.C.K.; Kareiva, A. Undoped and Eu ${ }^{3+}$ Doped Magnesium-Aluminium Layered Double Hydroxides: Peculiarities of Intercalation of Organic Anions and Investigation of Luminescence Properties. Materials 2019, 12, 736. [CrossRef] [PubMed]

46. Jaafar, A.; Hecker, C.; Árki, P.; Joseph, Y. Sol-Gel Derived Hydroxyapatite Coatings for Titanium Implants: A Review. Bioengineering 2020, 7, 127. [CrossRef] [PubMed]

47. Grazenaite, E.; Garskaite, E.; Stankeviciute, Z.; Raudonyte-Svirbutaviciene, E.; Zarkov, A.; Kareiva, A. Ga-Substituted CobaltChromium Spinels as Ceramic Pigments Produced by Sol-Gel Synthesis. Crystals 2020, 10, 1078. [CrossRef]

48. Karbovnyk, I.; Borshchyshyn, I.; Vakhula, Y.; Lutsyuk, I.; Klym, H.; Bolesta, I. Impedance characterization of $\mathrm{Cr}^{3+}$, $\mathrm{Y}^{3+}$ and $\mathrm{Zr}^{4+}$ activated forsterite nanoceramics synthesized by sol-gel method. Ceram. Int. 2016, 42, 8501-8504. [CrossRef]

49. Sperling, L.H. Interpenetrating Polymer Networks and Related Materials; Springer Science \& Business Media: Cham, Switzerland, 2012.

50. Lipatov, Y.S.; Alekseeva, T. Phase-separated interpenetrating polymer networks. In Advances in Polymer Science; Springer: Berlin, Germany, 2007; Volume 208, pp. 147-194. ISBN 978-3-540-73071-2.

51. Widmaier, J.-M.; Bonilla, G. In situ synthesis of optically transparent interpenetrating organic/inorganic networks. Polym. Adv. Technol. 2006, 17, 634-640. [CrossRef]

52. Bonilla, G.; Martinez, M.; Mendoza, A.M.; Widmaier, J.-M. Ternary interpenetrating networks of polyurethane-poly(methyl methacrylate)-silica. Preparation by sol-gel process and characterization of films. Eur. Polym. J. 2006, 42, 2977-2986. [CrossRef]

53. Nielsen, L.E.; Landel, R.F. Mechanical Properties of Polymers and Composites; CRC Press: Boca Raton, FL, USA, 1993; p. 580, ISBN 9780824789640.

54. Beckman, E.J.; Karasz, F.E.; Porter, R.S.; MacKnight, W.J.; Van Hunsel, J.; Koningsveld, R. Estimation of the interfacial fraction in partially miscible polymer blends from DSC measurements. Macromolecules 1988, 21, 1193-1194. [CrossRef]

55. Lee, L.H.; Chen, W.C. High-Refractive-index thin films prepared from trialkoxysilane-capped poly(methyl methacrylate)-titania materials. Chem. Mater. 2001, 13, 1137-1142. [CrossRef] 
56. Bach, L.G.; Islam, M.R.; Seo, S.Y.; Lim, K.T. A novel route for the synthesis of poly (2-hydroxyethyl methacrylate) grafted TiO 2 nanoparticles via surface thiol-lactam initiated radical polymerization. J. Appl. Polym. Sci. 2013, 127, 261-269. [CrossRef]

57. $\mathrm{Wu}, \mathrm{C} . \mathrm{S}$. In situ polymerization of titanium isopropoxide in polycaprolactone: Properties and characterization of the hybrid nanocomposites. J. Appl. Polym. Sci. 2004, 92, 1749-1757. [CrossRef]

58. Chen, W.; Lee, S.; Lee, L.; Lin, J. Synthesis and Characterization of Trialkoxysilane-Capped Poly (Methyl Methacrylate)-titania Hybrid Optical Thin Films. J. Mater. Chem. 1999, 9, 2999-3003. [CrossRef]

59. Rozenberg, B.A.; Boiko, G.N.; Bogdanova, L.M.; Dzhavadyan, E.A.; Komarov, B.A. Mechanism of anionic polymerization of 2-hydroxyethyl (meth) acrylates initiated by alkali metals and their alkoxides. Polym. Sci. Ser. A 2003, 45, 819-825.

60. Feld, R.; Cowe, P.L. Organic Chemistry of Titanium; Butterworth \& Co Publishers Ltd.: London, UK, 1965; 222p, ISBN 13 978-0408283007.

61. Trabelsi, S.; Janke, A.; Hässler, R.; Zafeiropoulos, N.E.; Fornasieri, G.; Bocchini, S.; Rozes, L.; Stamm, M.; Gérard, J.-F.; Sanchez, C. Novel Organo-functional titanium-oxo-cluster-based hybrid materials with enhanced thermomechanical and thermal properties. Macromolecules 2005, 38, 6068-6078. [CrossRef]

62. Ignatova, T.D.; Kosyanchuk, L.F.; Todosiychuk, T.T.; Nesterov, A.E. Reaction-induced phase separation and structure formation in polymer blends. Compos. Interfaces 2011, 18, 185-236. [CrossRef]

63. Lipatov, Y.S.; Nesterov, A.E. Thermodynamics of Polymer Blends; Techn. Publ. Co.: Basel, Switzerland, 1997; 450p.

64. Hourston, D.J.; Schäfer, F.U. Polyurethane/Polystyrene Oneshot Interpenetrating Polymer Networks with Good Damping Ability: Transition Broadening Through Crosslinking, Internetwork Grafting and Compatibilization. Polym. Adv. Technol. 1996, 7, 273-280. Available online: https:/ / onlinelibrary.wiley.com (accessed on 28 February 2021). [CrossRef]

65. Serga, V.; Burve, R.; Krumina, A.; Romanova, M.; Kotomin, E.A.; Popov, A.I. Extraction-Pyrolytic Method for TiO 2 Polymorphs Production. Crystals 2021, 11, 431. [CrossRef]

66. Serga, V.; Burve, R.; Krumina, A.; Pankratova, V.; Popov, A.I.; Pankratov, V. Study of phase composition, photocatalytic activity, and photoluminescence of $\mathrm{TiO}_{2}$ with Eu additive produced by the extraction-pyrolytic method. J. Mater. Res. Technol. 2021, 13, 2350-2360. [CrossRef]

67. Serikov, T.M.; Ibrayev, N.K.; Isaikina, O.Y.; Savilov, S.V. Nanocrystalline $\mathrm{TiO}_{2}$ Films: Synthesis and Low-Temperature Luminescent and Photovoltaic Properties. Russ. J. Inorg. Chem. 2021, 66, 117-123. [CrossRef] 